Endocrinol Metab Clin North Am. 2010 June ; 39(2): 243-253. doi:10.1016/j.ecl.2010.02.002.

\title{
Vitamin D: Metabolism
}

\author{
Sylvia Christakos, Ph.D. ${ }^{a}$, Dare V. Ajibade, B.A. ${ }^{b}$, Puneet Dhawan, Ph.D. ${ }^{C}$, Adam J. Fechner, \\ M.D.d, and Leila J. Mady, B.A.b \\ a Professor, Department of Biochemistry and Molecular Biology, University of Medicine and \\ Dentistry of New Jersey, New Jersey Medical School, Newark, New Jersey \\ ${ }^{\mathrm{b}} \mathrm{MD} / \mathrm{Ph}$.D. student, Department of Biochemistry and Molecular Biology, University of Medicine and \\ Dentistry of New Jersey, New Jersey Medical School, Newark, New Jersey \\ ${ }^{c}$ Assistant Professor, Department of Biochemistry and Molecular Biology, University of Medicine \\ and Dentistry of New Jersey, New Jersey Medical School, Newark, New Jersey \\ d Post doctoral fellow, Department of Obstetrics and Gynecology and Women's Health, University \\ of Medicine and Dentistry of New Jersey, New Jersey Medical School, Newark New Jersey
}

\section{Synopsis}

The biologically active metabolite of vitamin $\mathrm{D}, 1,25(\mathrm{OH})_{2} \mathrm{D}_{3}$, affects mineral homeostasis and has numerous other diverse physiological functions including effects on growth of cancer cells and protection against certain immune disorders. This chapter reviews the role of vitamin D hydroxylases in providing a tightly regulated supply of $1,25(\mathrm{OH})_{2} \mathrm{D}_{3}$. The role of extrarenal $1 \alpha(\mathrm{OH})$ ase in placenta and macrophages is also discussed as well as regulation of the hydroxylases and vitamin $\mathrm{D}$ hydroxylases in aging and chronic kidney disease. Understanding specific factors involved in regulating the hydroxylases may lead to the design of drugs that can selectively modulate the hydroxylases. The ability to alter levels of these enzymes would have therapeutic potential for the treatment of various diseases including bone loss disorders and certain immune diseases.

\section{Keywords}

vitamin D metabolites; vitamin D hydroxylases; vitamin D binding protein; FGF-23; kidney; placenta

\section{SYNTHESIS OF $1,25(\mathrm{OH})_{2} \mathrm{D}_{3}$ FROM VITAMIN $\mathrm{D}_{3}$}

Vitamin $\mathrm{D}_{3}$ (cholecalciferol) is taken in the diet (from fortified dairy products and fish oils) or is synthesized in the skin from 7-dehydrocholesterol by ultraviolet irradiation. The vitamin D produced by 7-dehydrocholesterol depends on the intensity of UV irradiation which varies with season and latitude (1). Sunscreen and clothing have been reported to prevent the conversion of 7-dehydrocholesterol to vitamin $\mathrm{D}_{3}(2,3)$. In order to be biologically active and affect mineral

\footnotetext{
${ }^{\mathrm{a}}$ Corresponding author for proofs and reprints: Sylvia Christakos, Ph.D., UMDNJ-New Jersey Medical School, Dept. of Biochem. and Molecular Biology, 185 South Orange Ave. E609, Newark, New Jersey 07103, 9739724033 (phone), 9739725594 (fax), christak@umdnj.edu.

${ }^{b^{c} C o-a u t h o r s ~ a d d r e s s e s: ~ D a r e ~ V . ~ A j i b a d e ~(a j i b a d d a @ u m d n j . e d u), ~ P u n e e t ~ D h a w a n ~(d h a w a n p u @ u m d n j . e d u), ~ L e i l a ~ J . ~ M a d y ~}$ (mady.leila@umdnj.edu), (same address and FAX as S. Christakos), phone: 9739727034

d Co-author: Adam J. Fechner (fechnead@umdnj.edu), (same address and Fax as S. Christakos except Dept. of Obstetrics, Gynecology and Women's Health - phone: 9739727034

Publisher's Disclaimer: This is a PDF file of an unedited manuscript that has been accepted for publication. As a service to our customers we are providing this early version of the manuscript. The manuscript will undergo copyediting, typesetting, and review of the resulting proof before it is published in its final citable form. Please note that during the production process errors may be discovered which could affect the content, and all legal disclaimers that apply to the journal pertain.
} 
metabolism and to have effects on numerous other diverse physiological functions including inhibition of growth of cancer cells and protection against certain immune mediated disorders, vitamin $\mathrm{D}$ most be converted to its active form $(4,5)$. Vitamin $\mathrm{D}$ is transported in the blood by the vitamin D binding protein (DBP, a specific binding protein for vitamin $D$ and its metabolites in serum) to the liver. In the liver vitamin $\mathrm{D}$ is hydroxylated at $\mathrm{C}-25$ by one or more cytochrome P450 vitamin D 25 hydroxylases (including CYP2R1, CYP2D11 and CYP2D25), resulting in the formation of 25-hydroxyvitamin $\mathrm{D}_{3}\left(25(\mathrm{OH}) \mathrm{D}_{3}\right)$. It has been suggested that CYP2R1 is the key enzyme required for 25 hydroxylation of vitamin $\mathrm{D}$ since a homozygous mutation of the CYP2R1 gene was found in a patient with low circulating levels of $25(\mathrm{OH}) \mathrm{D}_{3}$ and classic symptoms of vitamin $\mathrm{D}$ deficiency (6). $25(\mathrm{OH}) \mathrm{D}_{3}$, the major circulating form of vitamin $\mathrm{D}$, is transported by the DBP to the kidney. In the kidney, magalin, a member of the LDL receptor superfamily, plays an essential role in endocytic internalization of $25(\mathrm{OH}) \mathrm{D}_{3}(7)$. In the proximal renal tubule $25(\mathrm{OH}) \mathrm{D}_{3}$ is hydroxylated at the position of carbon 1 of the A ring, resulting in the hormonally active from of vitamin $\mathrm{D}, 1,25$-dihydroxyvitamin $\mathrm{D}_{3}(1,25$ $(\mathrm{OH})_{2} \mathrm{D}_{3}$ ) which is responsible for most, if not all of the biological actions of vitamin D (Fig. 1). The cytochrome $\mathrm{P} 450$ monooxygenase $25(\mathrm{OH}) \mathrm{D} 1 \alpha$ hydroxylase (CYP27B1; $1 \alpha(\mathrm{OH})$ ase) which metabolizes $25(\mathrm{OH}) \mathrm{D}_{3}$ to $1,25(\mathrm{OH})_{2} \mathrm{D}_{3}$ is present predominantly in kidney. This enzyme is also found in extrarenal sites including placenta, monocytes and macrophages (811). As with all mitochondrial $\mathrm{P} 450$ containing enzymes, during the $1 \alpha(\mathrm{OH})$ ase reaction electrons are transferred from NADPH to NADPH-ferrodoxin reductase through ferrodoxin. Inactivating mutations in the $1 \alpha(\mathrm{OH})$ ase gene result in vitamin $\mathrm{D}$ dependency rickets (VDDR) type 1 in spite of normal intake of vitamin $\mathrm{D}$, indicating the importance of the $1 \alpha(\mathrm{OH})$ ase enzyme (12). Type 1 vitamin $\mathrm{D}$ dependent rickets is characterized by growth failure, hypocalcemia, elevated PTH, muscle weakness and radiologic findings typical of rickets (12). The $1 \alpha(\mathrm{OH})$ ase null mutant mouse has provided a mouse model of VDDR type 1 (13, 14). It is of interest that in these mice, in addition to rickets, reproductive and immune defects have been noted (13). Further studies are needed to test the role of $1 \alpha(\mathrm{OH})$ ase in extra renal sites that has been a matter of debate.

\section{ROLE OF THE VITAMIN D BINDING PROTEIN (DBP) IN VITAMIN D METABOLISM AND ACTION}

Studies using mice deficient in DBP have resulted in new insight into the role of DBP in vitamin D metabolism and action. Although DBP null (-l-) mice have markedly lower total serum levels of $25(\mathrm{OH}) \mathrm{D}$ and $1,25(\mathrm{OH})_{2} \mathrm{D}_{3}$ than wild type (WT) mice, the levels of serum calcium and PTH are normal in the DBP $-/-$ mice (15). In patients with reduced levels of circulating DBP, serum calcium levels have also been reported to be normal (16). More recent studies using DBP null mice have shown that DBP is important for total circulating $1,25(\mathrm{OH})_{2} \mathrm{D}_{3}$ but DBP does not influence the pool of $1,25(\mathrm{OH})_{2} \mathrm{D}_{3}$ that enters cells and affects the synthesis of vitamin $\mathrm{D}$ target proteins (17). Thus direct measurement of $1,25(\mathrm{OH})_{2} \mathrm{D}_{3}$ may not, in all cases, reflect the biologically active $1,25(\mathrm{OH})_{2} \mathrm{D}_{3}(16)$. This may be, in part, why $25(\mathrm{OH}) \mathrm{D}_{3}$, which is also more stable than $1,25(\mathrm{OH})_{2} \mathrm{D}_{3}$, is used to assess clinical vitamin $\mathrm{D}$ status. It has been suggested that the maintenance of normal serum calcium levels in the DBP null mice may be due to the ability of the vitamin $\mathrm{D}$ receptor to concentrate $1,25(\mathrm{OH})_{2} \mathrm{D}_{3}$ in tissues due to its high affinity for $1,25(\mathrm{OH})_{2} \mathrm{D}_{3}$, resulting in transcriptional regulation of genes involved in maintenance of calcium homeostasis (17).

\section{24-HYDROXYLASE (24(OH)ase)}

In addition to $1,25(\mathrm{OH})_{2} \mathrm{D}_{3}$, the kidney can also produce 24,25 dihydroxyvitamin $\mathrm{D} 3(24,25$ $\left.(\mathrm{OH})_{2} \mathrm{D}_{3}\right)$, a relatively inactive metabolite when compared to $1,25(\mathrm{OH})_{2} \mathrm{D}_{3}$. 25Hydroxyvitamin $\mathrm{D}_{3} 24$ hydroxylase (CYP24), also a mitochondrial P450 enzyme, can hydroxylate both $25(\mathrm{OH}) \mathrm{D}_{3}$ and $1,25(\mathrm{OH})_{2} \mathrm{D}_{3}(5)$. It has been suggested that the preferred 
substrate for $24(\mathrm{OH})$ ase is $1,25(\mathrm{OH})_{2} \mathrm{D}_{3}(18)$. Thus, $24(\mathrm{OH})$ ase limits the amount of 1,25 $(\mathrm{OH})_{2} \mathrm{D}_{3}$ in target tissues both by accelerating the catabolism of $1,25(\mathrm{OH})_{2} \mathrm{D}_{3}$ to $1,24,25$ $(\mathrm{OH})_{3} \mathrm{D}_{3}$ resulting in calcitroic acid or by producing $24,25(\mathrm{OH})_{2} \mathrm{D}_{3}$ thus decreasing the pool of $25(\mathrm{OH}) \mathrm{D}_{3}$ available for 1 hydroxylation (Fig. 1). Studies using $24(\mathrm{OH})$ ase null mutant mice provided the first direct evidence for a role for $24(\mathrm{OH})$ ase in the catabolism of $1,25(\mathrm{OH})_{2} \mathrm{D}_{3}$. $24(\mathrm{OH})$ ase null mutant mice are unable to clear $1,25(\mathrm{OH})_{2} \mathrm{D}_{3}$ from the bloodstream after both chronic and acute treatment with $1,25(\mathrm{OH})_{2} \mathrm{D}_{3}(19)$. Lack of $24(\mathrm{OH})$ ase resulted in impaired mineralization in intramembranous bones. This defect was normalized by crossing $24(\mathrm{OH})$ ase deficient mice to VDR ablated mice, indicating that elevated $1,25(\mathrm{OH})_{2} \mathrm{D}_{3}$ levels, and not the absence of $24,25(\mathrm{OH})_{2} \mathrm{D}_{3}$, was responsible for the abnormalities in bone. Thus, the main function of $24(\mathrm{OH})$ ase is vitamin D inactivation.

\section{REGULATION OF RENAL VITAMIN D HYDROXYLASES}

\section{A. by calcium, phosphate, PTH and $1,25(\mathrm{OH})_{2} \mathrm{D}_{3}$}

The wide spread effects of $1,25(\mathrm{OH})_{2} \mathrm{D}_{3}$ necessitate a tight regulation of its bioavailability and a process of activation and deactivation that occurs through a series of negative and positive feedbacks resulting in changes in the expression of the hydroxylase enzymes depending on the physiological state $(20,21)$. With regard to regulation of vitamin $\mathrm{D}$ metabolism, low dietary calcium and phosphate result in enhanced activity of $1 \alpha(\mathrm{OH})$ ase (5) (Fig. 1). Elevated PTH resulting from hypocalcemia is a primary signal mediating the induction of $1,25(\mathrm{OH})_{2} \mathrm{D}_{3}$ synthesis in the kidney (22-24). PTH stimulates the transcription of $1 \alpha(\mathrm{OH})$ ase (25-27). Recent studies have shown that the nuclear receptor 4A2 (NR4A2) is a key factor involved in the induction of $1 \alpha(\mathrm{OH})$ ase transcription by PTH (26). $1,25(\mathrm{OH})_{2} \mathrm{D}_{3}$ in turn suppresses PTH production at the level of transcription (28). The $1 \alpha(\mathrm{OH})$ ase gene is also negatively regulated by $1,25(\mathrm{OH})_{2} \mathrm{D}_{3}(29,30)$. When compared to the regulation of $1 \alpha(\mathrm{OH})$ ase, $24(\mathrm{OH})$ ase is reciprocally regulated (stimulated by $1,25(\mathrm{OH})_{2} \mathrm{D}_{3}$ and inhibited by low calcium and $\mathrm{PTH}$ ) (5). The marked induction of $24(\mathrm{OH})$ ase by $1,25(\mathrm{OH})_{2} \mathrm{D}_{3}$ results in an autoregulatory suppression of $1,25(\mathrm{OH})_{2} \mathrm{D}_{3}$ when gene transcriptional effects of $1,25(\mathrm{OH})_{2} \mathrm{D}_{3}$ need to be attenuated to protect against hypercalemia. Various factors that cooperate with the vitamin D receptor $(\mathrm{VDR})$ in the transcriptional regulation of $24(\mathrm{OH})$ ase have been identified including the transcription factor C/EBP $\beta, \mathrm{SWI} / \mathrm{SNF}$ (complexes that remodel chromatin using the energy of ATP hydrolysis) and histone methyltansferases (CARM1 and G9) (31-33). Recent studies have suggested a synergy between acetylated and methylated histones to disrupt histone/DNA binding resulting in enhanced VDR activation of 24(OH)ase transcription (33).

\section{B. by FGF23}

In addition to calcium, phosphate, $\mathrm{PTH}$ and $1,25(\mathrm{OH})_{2} \mathrm{D}_{3}$, fibroblast growth factor 23 (FGF23), a phosphaturic factor that promotes renal phosphate excretion by decreasing its reabsorption in the proximal tubule, is also a physiological regulator of vitamin D metabolism (34). Unlike classical FGFs that function via paracrine mechanisms, FGF23 belongs to the FGF19 subfamily that acts in an endocrine fashion (35). From its identification as a causative factor in autosomal dominant hypophophatemic rickets (ADHR), X-linked hypophosphatemic rickets (XLH), and tumor-induced osteomalacia (TIO), FGF23 has been shown to be a significant regulator of phosphate homeostasis and vitamin D biosynthesis (36-39). 1,25(OH ${ }_{2} \mathrm{D}_{3}$ stimulates the production of FGF23 in bone (40). Administration of $1,25(\mathrm{OH})_{2} \mathrm{D}_{3}$ to mice results in increased serum levels of FGF23 prior to elevations in serum phosphate, suggesting that $1,25(\mathrm{OH})_{2} \mathrm{D}_{3}$ induces FGF23 expression independent of changes in serum phosphate (40). Increased FGF23 in turn suppresses the expression of $1 \alpha(\mathrm{OH})$ ase and induces $24(\mathrm{OH})$ ase in kidney (41) (Fig. $1,2)$. By inhibiting synthesis and promoting catabolism of $1,25(\mathrm{OH})_{2} \mathrm{D}_{3}, \mathrm{FGF} 23$ functions to reduce levels of $1,25(\mathrm{OH})_{2} \mathrm{D}_{3}$, which in turn decreases FGF23 expression in bone, forming a negative feedback circuit between the FGF23 and the vitamin D endocrine system (41). 
Overactivity of FGF23 has been suggested to be a common pathogenic mechanism of phosphate wasting disorders that may explain their shared clinical characteristics including hypophosphatemia, low serum $1,25(\mathrm{OH})_{2} \mathrm{D}_{3}$, and rickets/osteomalacia (41).

It has been reported that FGF23 requires klotho (a multifunctional protein involved in phosphate and calcium homeostasis) as a cofactor for FGF signaling (42). Expressed predominantly in the kidney and also in parathyroid gland and choroid plexus (43), the klotho gene was first identified when mice homozygous for the gene mutation developed a syndrome resembling human premature-ageing, including a short lifespan, infertility, arteriosclerosis, skin atrophy, osteoporosis and emphysema (44). $1,25(\mathrm{OH})_{2} \mathrm{D}_{3}$ up-regulates klotho gene expression in kidney and the loss of klotho results in induction of $1 \alpha(\mathrm{OH})$ ase, suggesting that klotho participates in $1,25(\mathrm{OH})_{2} \mathrm{D}_{3}$ autoregulatory suppression (45). Klotho can bind to several FGF receptor isoforms and can convert the canonical FGF receptor to a receptor specific for FGF23 (46). The cooperation of klotho and FGF23 in a common signal transduction pathway (Fig 2) may explain why klotho-deficient mice and FGF23-deficient mice exhibit identical phenotypes including premature ageing and metabolic disturbances such as hyperphosphatemia and increased synthesis of $1,25(\mathrm{OH})_{2} \mathrm{D}_{3}(45,47,48)$.

\section{C. by other hormones (sex hormones, calcitonin, prolactin)}

In avian species estrogens alone or when combined with androgens or progesterone have been reported to stimulate $1,25(\mathrm{OH})_{2} \mathrm{D}_{3}$ production $(49,50)$. In addition, estrogens have been reported to suppress $24,25(\mathrm{OH})_{2} \mathrm{D}_{3}$ synthesis (49). However whether this relationship exists in mammalian species has been a matter of debate (51).

Although calcitonin is known to have a role in shrinking osteoclasts under high calcium conditions, under conditions where serum calcium levels are normal calcitonin has been reported to stimulate $1,25(\mathrm{OH})_{2} \mathrm{D}_{3}$ production (52-54). The stimulation of $1,25(\mathrm{OH})_{2} \mathrm{D}_{3}$ production by calcitonin may have physiological significance during lactation when calcitonin levels as well as $1,25(\mathrm{OH})_{2} \mathrm{D}_{3}$ levels are elevated and when the need for calcium is increased $(55,56)$. Recent studies have shown a direct effect of calcitonin on renal $1 \alpha(\mathrm{OH})$ ase transcription (57). The transcription factor C/EBP $\beta$ and the SWI/SNF chromatin remodeling complex were found to mediate the calcitonin regulation of $1 \alpha(\mathrm{OH})$ ase transcription, indicating a mechanism responsible, at least in part, for the increase in plasma $1,25(\mathrm{OH})_{2} \mathrm{D}_{3}$ during these times of increased calcium requirement (57).

It has been suggested that prolactin, which is also elevated during lactation, can stimulate 1,25 $(\mathrm{OH})_{2} \mathrm{D}_{3}$ production. Bromocriptine, which inhibits pituitary prolactin secretion, has been reported to significantly reduce plasma $1,25(\mathrm{OH})_{2} \mathrm{D}_{3}$ levels in lactating animals and recent studies have shown that prolactin also has a direct effect on the transcription of the $1 \alpha(\mathrm{OH})$ ase gene $(58,59)$. Clinical studies have also suggested that factors besides PTH stimulate $1 \alpha(\mathrm{OH})$ ase during lactation. For example, lactating hypoparathyroid women treated with the usual dose of calcitriol have been reported to develop hypercalcemia. In the absence of treatment, serum $1,25(\mathrm{OH})_{2} \mathrm{D}_{3}$ levels in the hypoparathyroid women remain within the normal range during lactation $(60,61)$. Thus, it is likely that prolactin and calcitonin have a physiological function to increase $1,25(\mathrm{OH})_{2} \mathrm{D}_{3}$ levels during lactation to protect the maternal skeleton.

\section{EXTRARENAL 1-HYDROXYLASE (1 $\alpha(\mathrm{OH})$ ase $)$}

\section{A. Placenta}

In pregnancy, the placenta regulates communication and transport between mother and fetus, with the placental trophoblasts and maternal decidua serving as the functional interface for exchange. $1 \alpha(\mathrm{OH})$ ase is expressed in both fetal trophoblast and maternal decidual cells beginning early in gestation (62). $1 \alpha(\mathrm{OH})$ ase is most abundant in decidua (62). Synthesis of 
$1 \alpha(\mathrm{OH})$ ase is 8 fold higher in first trimester decidual cells than in third trimester cells (63). This trend indicates an important role for $1,25(\mathrm{OH})_{2} \mathrm{D}_{3}$ in early pregnancy. It has been suggested that the immunosuppressive effects of $1,25(\mathrm{OH})_{2} \mathrm{D}_{3}$ are crucial for allowing proper trophoblast invasion of the uterus without triggering a maternal immune response (62). Decidual natural killer cells isolated from the first trimester decidua show decreased synthesis of cytokines such as tumor necrosis factor and interleukin 6 in response to $1,25(\mathrm{OH})_{2} \mathrm{D}_{3}(63)$. A role of $1,25(\mathrm{OH})_{2} \mathrm{D}_{3}$ as an activator of innate immunity in the placenta has also been suggested. It has been shown that in trophoblasts $1,25(\mathrm{OH})_{2} \mathrm{D}_{3}$ increases the expression of cathelicidin, an antimicrobial peptide (64). In addition to upregulation of $1 \alpha(\mathrm{OH})$ ase expression, recent findings indicate that the increased bioavailability of $1,25(\mathrm{OH})_{2} \mathrm{D}_{3}$ at the fetomaternal interface may also be partially attributed to a decrease in activity of the catabolic $24(\mathrm{OH})$ ase enzyme in placenta (65). Taken together, these findings suggest the importance of the local production of $1,25(\mathrm{OH})_{2} \mathrm{D}_{3}$ in the placenta to regulate both acquired and innate immune responses and a possible role for $1,25(\mathrm{OH})_{2} \mathrm{D}_{3}$ in the immunoregulation of implantation.

\section{B. Monocytes/macrophages}

Monocytes and macrophages express $1 \alpha(\mathrm{OH})$ ase and produce $1,25(\mathrm{OH})_{2} \mathrm{D}_{3}$. However, monocyte/macrophage $1 \alpha(\mathrm{OH})$ ase is regulated differently than renal $1 \alpha(\mathrm{OH})$ ase $(10,11)$. Clinical evidence for a different regulation of macrophage $1 \alpha(\mathrm{OH})$ ase is observed in patients with sarcoidosis. In sarcoidosis patients there is increased production of $1,25(\mathrm{OH})_{2} \mathrm{D}_{3}$ despite hypercalcemia (66). The disordered calcium homeostasis in sarcoidosis is due to dysregulated production of $1,25(\mathrm{OH})_{2} \mathrm{D}_{3}$ by activated macrophages (66). Unlike renal $1 \alpha(\mathrm{OH})$ ase, $1 \alpha(\mathrm{OH})$ ase produced by macrophages is not suppressed by elevated calcium or $1,25(\mathrm{OH})_{2} \mathrm{D}_{3}$ and is upregulated by immune stimuli such as interferon gamma (IFN- $\gamma$ ) and lipopolysaccharide (LPS) $(10,11)$. Multiple pathways have been reported to be involved in this upregulation, including JAK/STAT, MAPK, and NFאB (10). Activation of $1 \alpha(\mathrm{OH})$ ase transcription by immune stimuli also requires the binding of C/EBP $\beta$ to its recognition sites in the $1 \alpha(\mathrm{OH})$ ase promoter region $(10,11)$. These findings suggest mechanisms responsible for the hypercalcemia of granulomatous disorders in which activated macrophages constitutively express $1 \alpha(\mathrm{OH})$ ase in the presence of elevated calcium and $1,25(\mathrm{OH})_{2} \mathrm{D}_{3}$.

\section{VITAMIN D P450s IN AGING AND CHRONIC KIDNEY DISEASE}

The capacity of the kidney to convert $25(\mathrm{OH}) \mathrm{D}_{3}$ to $1,25(\mathrm{OH})_{2} \mathrm{D}_{3}$ has been reported to decline with age. An increase in $24(\mathrm{OH})$ ase gene expression and an increase in clearance of 1,25 $(\mathrm{OH})_{2} \mathrm{D}_{3}$ with aging have been reported (67-69). These findings suggest that the combined effect of a decline in the ability of the kidney to synthesize $1,25(\mathrm{OH})_{2} \mathrm{D}_{3}$ and an increase in renal metabolism of $1,25(\mathrm{OH})_{2} \mathrm{D}_{3}$ may contribute to age related bone loss.

Chronic kidney disease (CKD) has been shown to result in decreased vitamin D metabolism through multiple mechanisms (70). The loss of functional renal mass leads to decreased production of $1 \alpha(\mathrm{OH})$ ase, specifically in the later stages of CKD (70). However, studies have also shown a suppression of enzyme activity due to associated aspects of the disease, including metabolic acidosis (71), hyperphosphatemia (72) and uremic toxins that accumulate in CKD (73). Elevated levels of FGF23 have also been shown in early CKD, resulting in decreased activity of $1 \alpha(\mathrm{OH})$ ase. (74).

In summary, understanding vitamin D metabolism is of fundamental importance in understanding mechanisms involved in the maintenance of calcium homeostasis. The vitamin D hydroxylases have an important role in providing a tightly regulated supply of 1,25

$(\mathrm{OH})_{2} \mathrm{D}_{3}$. Understanding specific factors involved in regulating the hydroxylases may lead to the design of drugs that can selectively modulate the hydroxylases. The ability to alter levels 
of these enzymes would have therapeutic potential for the treatment of various diseases including bone loss disorders and certain immune diseases.

\section{Acknowledgments}

Studies referenced from the laboratory of S. Christakos were supported in part by NIH grant DK-38961-21

\section{References}

1. Webb AR, Kline L, Holick MF. Influence of season and latitude on the cutaneous synthesis of vitamin D3: exposure to winter sunlight in Boston and Edmonton will not promote vitamin D3 synthesis in human skin. J Clin Endocrinol Metab 1988;67:373-8. [PubMed: 2839537]

2. Matsuoka LY, Ide L, Wortsman J, et al. Sunscreens suppress cutaneous vitamin D3 synthesis. J Clin Endocrinol Metab 1987;64:1165-8. [PubMed: 3033008]

3. Matsuoka LY, Wortsman J, Dannenberg MJ, et al. Clothing prevents ultraviolet-B radiation-dependent photosynthesis of vitamin D3. J Clin Endocrinol Metab 1992;75:1099-103. [PubMed: 1328275]

4. Prosser DE, Jones G. Enzymes involved in the activation and inactivation of vitamin D. Trends Biochem Sci 2004;29:664-73. [PubMed: 15544953]

5. Omdahl JL, Morris HA, May BK. Hydroxylase enzymes of the vitamin D pathway: expression, function, and regulation. Annu Rev Nutr 2002;22:139-66. [PubMed: 12055341]

6. Cheng JB, Levine MA, Bell NH, et al. Genetic evidence that the human CYP2R1 enzyme is a key vitamin D 25-hydroxylase. Proc Natl Acad Sci U S A 2004;101:7711-5. [PubMed: 15128933]

7. Nykjaer A, Dragun D, Walther D, et al. An endocytic pathway essential for renal uptake and activation of the steroid 25-(OH) vitamin D3. Cell 1999;96:507-15. [PubMed: 10052453]

8. Weisman Y, Harell A, Edelstein S, et al. 1 alpha, 25-Dihydroxyvitamin D3 and 24,25dihydroxyvitamin D3 in vitro synthesis by human decidua and placenta. Nature 1979;281:317-9. [PubMed: 551281]

9. Gray TK, Lester GE, Lorenc RS. Evidence for extra-renal 1 alpha-hydroxylation of 25-hydroxyvitamin D3 in pregnancy. Science 1979;204:1311-3. [PubMed: 451538]

10. Stoffels K, Overbergh L, Bouillon R, et al. Immune regulation of 1alpha-hydroxylase in murine peritoneal macrophages: unravelling the IFNgamma pathway. J Steroid Biochem Mol Biol 2007;103:567-71. [PubMed: 17267208]

11. Esteban L, Vidal M, Dusso A. 1alpha-Hydroxylase transactivation by gamma-interferon in murine macrophages requires enhanced C/EBPbeta expression and activation. J Steroid Biochem Mol Biol 2004;89-90:131-7.

12. Kitanaka S, Takeyama K, Murayama A, et al. Inactivating mutations in the 25-hydroxyvitamin D3 1alpha-hydroxylase gene in patients with pseudovitamin D-deficiency rickets. N Engl J Med 1998;338:653-61. [PubMed: 9486994]

13. Panda DK, Miao D, Tremblay ML, et al. Targeted ablation of the 25-hydroxyvitamin D 1alpha hydroxylase enzyme: evidence for skeletal, reproductive, and immune dysfunction. Proc Natl Acad Sci U S A 2001;98:7498-503. [PubMed: 11416220]

14. Dardenne O, Prud'homme J, Arabian A, et al. Targeted inactivation of the 25-hydroxyvitamin D(3)-1 (alpha)-hydroxylase gene (CYP27B1) creates an animal model of pseudovitamin D-deficiency rickets. Endocrinology 2001;142:3135-41. [PubMed: 11416036]

15. Safadi FF, Thornton P, Magiera H, et al. Osteopathy and resistance to vitamin D toxicity in mice null for vitamin D binding protein. J Clin Invest 1999;103:239-51. [PubMed: 9916136]

16. Bikle DD, Siiteri PK, Ryzen E, et al. Serum protein binding of 1,25-dihydroxyvitamin D: a reevaluation by direct measurement of free metabolite levels. J Clin Endocrinol Metab 1985;61:96975. [PubMed: 3840175]

17. Zella LA, Shevde NK, Hollis BW, Cooke NE, Pike JW. Vitamin D-binding protein influences total circulating levels of 1,25-dihydroxyvitamin D3 but does not directly modulate the bioactive levels of the hormone in vivo. Endocrinology 2008;149:3656-67. [PubMed: 18372326] 
18. Shinki T, Jin CH, Nishimura A, et al. Parathyroid hormone inhibits 25-hydroxyvitamin D3-24hydroxylase mRNA expression stimulated by 1 alpha,25-dihydroxyvitamin D3 in rat kidney but not in intestine. J Biol Chem 1992;267:13757-62. [PubMed: 1618870]

19. St-Arnaud R, Arabian A, Travers R, et al. Deficient mineralization of intramembranous bone in vitamin D-24-hydroxylase-ablated mice is due to elevated 1,25-dihydroxyvitamin $\mathrm{D}$ and not to the absence of 24,25-dihydroxy vitamin D. Endocrinology 2000;141:2658-66. [PubMed: 10875271]

20. Henry HL, Norman AW. Vitamin D: metabolism and biological actions. Annu Rev Nutr 1984;4:493520. [PubMed: 6087861]

21. DeLuca HF. Evolution of our understanding of vitamin D. Nutr Rev 2008;66:S73-87. [PubMed: 18844850]

22. Boyle IT, Gray RW, DeLuca HF. Regulation by calcium of in vivo synthesis of $1,25-$ dihydroxycholecalciferol and 24,25-dihydroxycholecalciferol. Proc Natl Acad Sci U S A 1971;68:2131-4. [PubMed: 4332247]

23. Henry HL. Parathyroid hormone modulation of 25-hydroxyvitamin D3 metabolism by cultured chick kidney cells is mimicked and enhanced by forskolin. Endocrinology 1985;116:503-10. [PubMed: 2981664]

24. Murayama A, Takeyama K, Kitanaka S, et al. Positive and negative regulations of the renal 25hydroxyvitamin D3 1alpha-hydroxylase gene by parathyroid hormone, calcitonin, and 1alpha,25 $(\mathrm{OH}) 2 \mathrm{D} 3$ in intact animals. Endocrinology 1999;140:2224-31. [PubMed: 10218975]

25. Brenza HL, Kimmel-Jehan C, et al. Parathyroid hormone activation of the 25-hydroxyvitamin D3-1alpha-hydroxylase gene promoter. Proc Natl Acad Sci U S A 1998;95:1387-91. [PubMed: 9465024]

26. Zierold C, Nehring JA, DeLuca HF. Nuclear receptor 4A2 and C/EBPbeta regulate the parathyroid hormone-mediated transcriptional regulation of the 25-hydroxyvitamin D3-1alpha-hydroxylase. Arch Biochem Biophys 2007;460:233-9. [PubMed: 17224121]

27. Murayama A, Takeyama K, Kitanaka S, et al. The promoter of the human 25-hydroxyvitamin D3 1 alpha-hydroxylase gene confers positive and negative responsiveness to $\mathrm{PTH}$, calcitonin, and 1 alpha, 25(OH)2D3. Biochem Biophys Res Commun 1998;249:11-6. [PubMed: 9705822]

28. Kim MS, Fujiki R, Murayama A, et al. 1Alpha,25(OH)2D3-induced transrepression by vitamin D receptor through E-box-type elements in the human parathyroid hormone gene promoter. Mol Endocrinol 2007;21:334-42. [PubMed: 17095575]

29. Brenza HL, DeLuca HF. Regulation of 25-hydroxyvitamin D3 1alpha-hydroxylase gene expression by parathyroid hormone and 1,25-dihydroxyvitamin D3. Arch Biochem Biophys 381:143-52. [PubMed: 11019830]

30. Murayama A, Kim MS, Yanagisawa J, et al. 2004 Transrepression by a liganded nuclear receptor via a bHLH activator through co-regulator switching. EMBO J 2000;23:1598-608. [PubMed: 15934135]

31. Dhawan P, Peng X, Sutton AL, et al. Functional cooperation between CCAAT/enhancer-binding proteins and the vitamin D receptor in regulation of 25-hydroxyvitamin D3 24-hydroxylase. Mol Cell Biol 2005;25:472-87. [PubMed: 15601867]

32. Christakos S, Dhawan P, Shen Q, et al. New insights into the mechanisms involved in the pleiotropic actions of 1,25dihydroxyvitamin D3. Ann N Y Acad Sci 2006;1068:194-203. [PubMed: 16831919]

33. Zhong Y, Christakos S. 2006 Novel mechanism of vitamin D receptor (VDR) Activation: Histone H3 lysine 9 methyltransferase is a transcriptional coativator for VDR. J Bone Miner Res 2007;22 (suppl 1):S8.

34. Bai X, Miao D, Li J, et al. Transgenic mice overexpressing human fibroblast growth factor 23 (R176Q) delineate a putative role for parathyroid hormone in renal phosphate wasting disorders. Endocrinology 2004;145:5269-79. [PubMed: 15284207]

35. Goetz R, Beenken A, Ibrahimi OA, et al. Molecular insights into the klotho-dependent, endocrine mode of action of fibroblast growth factor 19 subfamily members. Mol Cell Biol 2007;27:3417-28. [PubMed: 17339340]

36. ADHR Consortium. Autosomal dominant hypophosphataemic rickets is associated with mutations in FGF23. Nat Genet 2000;26:345-8. [PubMed: 11062477]

37. Shimada T, Mizutani S, Muto T, et al. Cloning and characterization of FGF23 as a causative factor of tumor-induced osteomalacia. Proc Natl Acad Sci U S A 2001;98:6500-5. [PubMed: 11344269] 
38. White KE, Carn G, Lorenz-Depiereux B, et al. Autosomal-dominant hypophosphatemic rickets (ADHR) mutations stabilize. FGF-23 Kidney Int 2001;60:2079-86.

39. Weber TJ, Liu S, Indridason OS, et al. Serum FGF23 levels in normal and disordered phosphorus homeostasis. J Bone Miner Res 2003;18:1227-34. [PubMed: 12854832]

40. Liu S, Tang W, Zhou J, et al. Fibroblast growth factor 23 is a counter-regulatory phosphaturic hormone for vitamin D. J Am Soc Nephrol 2006;17:1305-15. [PubMed: 16597685]

41. Shimada T, Kakitani M, Yamazaki Y, et al. Targeted ablation of Fgf23 demonstrates an essential physiological role of FGF23 in phosphate and vitamin D metabolism. J Clin Invest 2004;113:5618. [PubMed: 14966565]

42. Kurosu H, Ogawa Y, Miyoshi M, et al. Regulation of fibroblast growth factor-23 signaling by klotho. J Biol Chem 2006;281:6120-3. [PubMed: 16436388]

43. Imura A, Tsuji Y, Murata M, et al. alpha-Klotho as a regulator of calcium homeostasis. Science 2007;316:1615-8. [PubMed: 17569864]

44. Kuro-o M, Matsumura Y, Aizawa H, et al. Mutation of the mouse klotho gene leads to a syndrome resembling ageing. Nature 1997;390:45-51. [PubMed: 9363890]

45. Tsujikawa H, Kurotaki Y, Fujimori T, et al. Klotho, a gene related to a syndrome resembling human premature aging, functions in a negative regulatory circuit of vitamin $\mathrm{D}$ endocrine system. Mol Endocrinol 2003;17:2393-403. [PubMed: 14528024]

46. Urakawa I, Yamazaki Y, Shimada T, et al. Klotho converts canonical FGF receptor into a specific receptor for FGF23. Nature 2006;444:770-4. [PubMed: 17086194]

47. Shimada T, Kakitani M, Yamazaki Y, et al. Targeted ablation of FGF23 demonstrates an essential physiological role of FGF23 in phosphate and vitamin D metabolism. J Clin Invest 2004;113:5618. [PubMed: 14966565]

48. Yoshida T, Fujimori T, Nabeshima Y. Mediation of unusually high concentrations of 1,25dihydroxyvitamin D in homozygous klotho mutant mice by increased expression of renal 1alphahydroxylase gene. Endocrinology 2002;143:683. [PubMed: 11796525]

49. Pike JW, Spanos E, Colston KW, et al. Influence of estrogen on renal vitamin D hydroxylases and serum 1alpha,25-(OH)2D3 in chicks. Am J Physiol 1978;235:E338-43. [PubMed: 211856]

50. Tanaka Y, Castillo L, Wineland MJ, et al. Synergistic effect of progesterone, testosterone, and estradiol in the stimulation of chick renal 25-hydroxyvitamin D3-1alpha-hydroxylase. Endocrinology 1978;103:2035-9. [PubMed: 748032]

51. Baksi SN, Kenny AD. Does estradiol stimulate in vivo production of 1,25-dihydroxyvitamin D3 in the rat? Life Sci 1978;22:787-92. [PubMed: 205752]

52. Shinki T, Ueno Y, DeLuca HF, et al. Calcitonin is a major regulator for the expression of renal 25hydroxyvitamin D3-1alpha-hydroxylase gene in normocalcemic rats. Proc Natl Acad Sci U S A 1999;96:8253-8. [PubMed: 10393981]

53. Kawashima H, Torikai S, Kurokawa K. Calcitonin selectively stimulates 25-hydroxyvitamin D3-1 alpha-hydroxylase in proximal straight tubule of rat kidney. Nature 1981;291:327-9. [PubMed: 7231553]

54. Galante L, Colston KW, MacAuley SJ, et al. Effect of calcitonin on vitamin D metabolism. Nature 1972;238:271-3. [PubMed: 4558556]

55. Stevenson JC, Hillyard CJ, MacIntyre I, et al. A physiological role for calcitonin: protection of the maternal skeleton. Lancet 1979;2:769-70. [PubMed: 90862]

56. Kumar R, Cohen WR, Silva P, et al. Elevated 1,25-dihydroxyvitamin D plasma levels in normal human pregnancy and lactation. J Clin Invest 1979;63:342-4. [PubMed: 429557]

57. Zhong Y, Armbrecht HJ, Christakos S. Calcitonin, a regulator of the 25-hydroxyvitamin D3 1alphahydroxylase gene. J Biol Chem 2009;284:11059-69. [PubMed: 19261615]

58. Robinson CJ, Spanos E, et al. Role of prolactin in vitamin D metabolism and calcium absorption during lactation in the rat. J Endocrinol 1982;94:443-53. [PubMed: 6896886]

59. Ajibade DV, Dhawan P, Christakos S. prolactin: A regulator of the 25-hydroxyvitaminD3 1alpha hydroxylase gene. J Bone Miner Res. 2009 in press. 
60. Cundy T, Haining SA, Guilland-Cumming DF, et al. Remission of hypoparathyroidism during lactation: evidence for a physiological role for prolactin in the regulation of vitamin D metabolism. Clin Endocrinol (Oxf) 1987;26:667-74. [PubMed: 3665123]

61. Caplan RH, Beguin EA. Hypercalcemia in a calcitriol-treated hypoparathyroid woman during lactation. Obstet Gynecol 1990;76:485-9. [PubMed: 2381632]

62. Zehnder D, Evans KN, Kilby MD, et al. The ontogeny of 25-hydroxyvitamin D(3) 1alpha-hydroxylase expression in human placenta and decidua. Am J Pathol 2002;161:105-14. [PubMed: 12107095]

63. Evans KN, Nguyen L, Chan J, et al. Effects of 25-hydroxyvitamin D3 and 1,25-dihydroxyvitamin D3 on cytokine production by human decidual cells. Biol Reprod 2006;75:816-22. [PubMed: 16957024]

64. Liu N, Kaplan AT, Low J, et al. Vitamin D induces innate antibacterial responses in human trophoblasts via an intracrine pathway. Biol Reprod 2009;80:398-406. [PubMed: 19005165]

65. Novakovic B, Sibson M, Ng HK, et al. Placenta-specific methylation of the vitamin D 24-hydroxylase gene: implications for feedback autoregulation of active vitamin D levels at the fetomaternal interface. J Biol Chem 2009;284:14838-48. [PubMed: 19237542]

66. Sharma OP. Hypercalcemia in granulomatous disorders: a clinical review. Curr Opin Pulm Med 2000;6:442-7. [PubMed: 10958237]

67. Armbrecht HJ, Zenser TV, Davis BB. Effect of age on the conversion of 25-hydroxyvitamin D3 to 1,25-dihydroxyvitamin D3 by kidney of rat. J Clin Invest 1980;66:1118-23. [PubMed: 6893596]

68. Matkovits T, Christakos S. Variable in vivo regulation of rat vitamin D-dependent genes (osteopontin, $\mathrm{Ca}, \mathrm{Mg}$-adenosine triphosphatase, and 25-hydroxyvitamin D3 24-hydroxylase): implications for differing mechanisms of regulation and involvement of multiple factors. Endocrinology 1995;136:3971-82. [PubMed: 7649106]

69. Tsai KS, Heath H 3rd, Kumar R, Riggs BL. Impaired vitamin D metabolism with aging in women Possible role in pathogenesis of senile osteoporosis. J Clin Invest 1984;73:1668-72. [PubMed: 6327768]

70. Cheng S, Coyne D. Vitamin D and outcomes in chronic kidney disease. Curr Opin Nephrol Hypertens 2007;16:77-82. [PubMed: 17293681]

71. Lee SW, Russell J, Avioli LV. 25-hydroxycholecalciferol to 1,25-dihydroxycholecalciferol: conversion impaired by systemic metabolic acidosis. Science 1977;195:994-6. [PubMed: 841324]

72. Portale AA, Booth BE, Halloran BP, et al. Effect of dietary phosphorus on circulating concentrations of 1,25-dihydroxyvitamin $\mathrm{D}$ and immunoreactive parathyroid hormone in children with moderate renal insufficiency. J Clin Invest 1984;73:1580-9. [PubMed: 6547151]

73. Hsu CH, Vanholder R, Patel S, et al. Subfractions in uremic plasma ultrafiltrate inhibit calcitriol metabolism. Kidney Int 1991;40:868-73. [PubMed: 1762291]

74. Gutierrez O, Isakova T, Rhee E, et al. Fibroblast growth factor-23 mitigates hyperphosphatemia but accentuates calcitriol deficiency in chronic kidney disease. J Am Soc Nephrol 2005;16:2205-15. [PubMed: 15917335] 


\section{7-dehydrocholesterol}

Skin $\downarrow$ UV

Vitamin $\mathbf{D}_{3}$

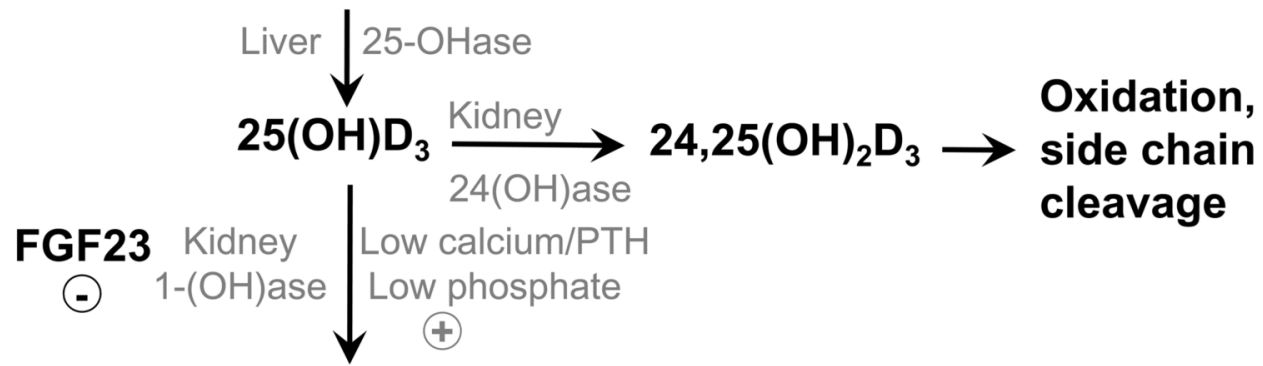

FGF23

$1,25(\mathrm{OH})_{2} \mathrm{D}_{3} \rightarrow$ Target tissues $\rightarrow$ Biological response

๑ 24(OH)ase $\downarrow$ 1,25(OH) ${ }_{2} \mathrm{D}_{3}$

$1,24,25(\mathrm{OH})_{3} \mathrm{D}_{3}$

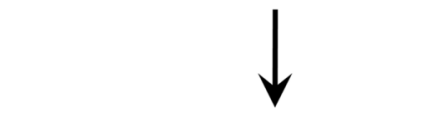

Oxidation, side chain cleavage

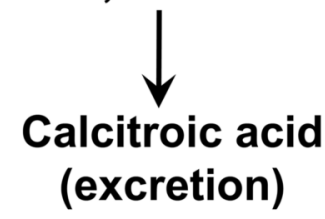

Figure 1.

The metabolic pathway for vitamin D 


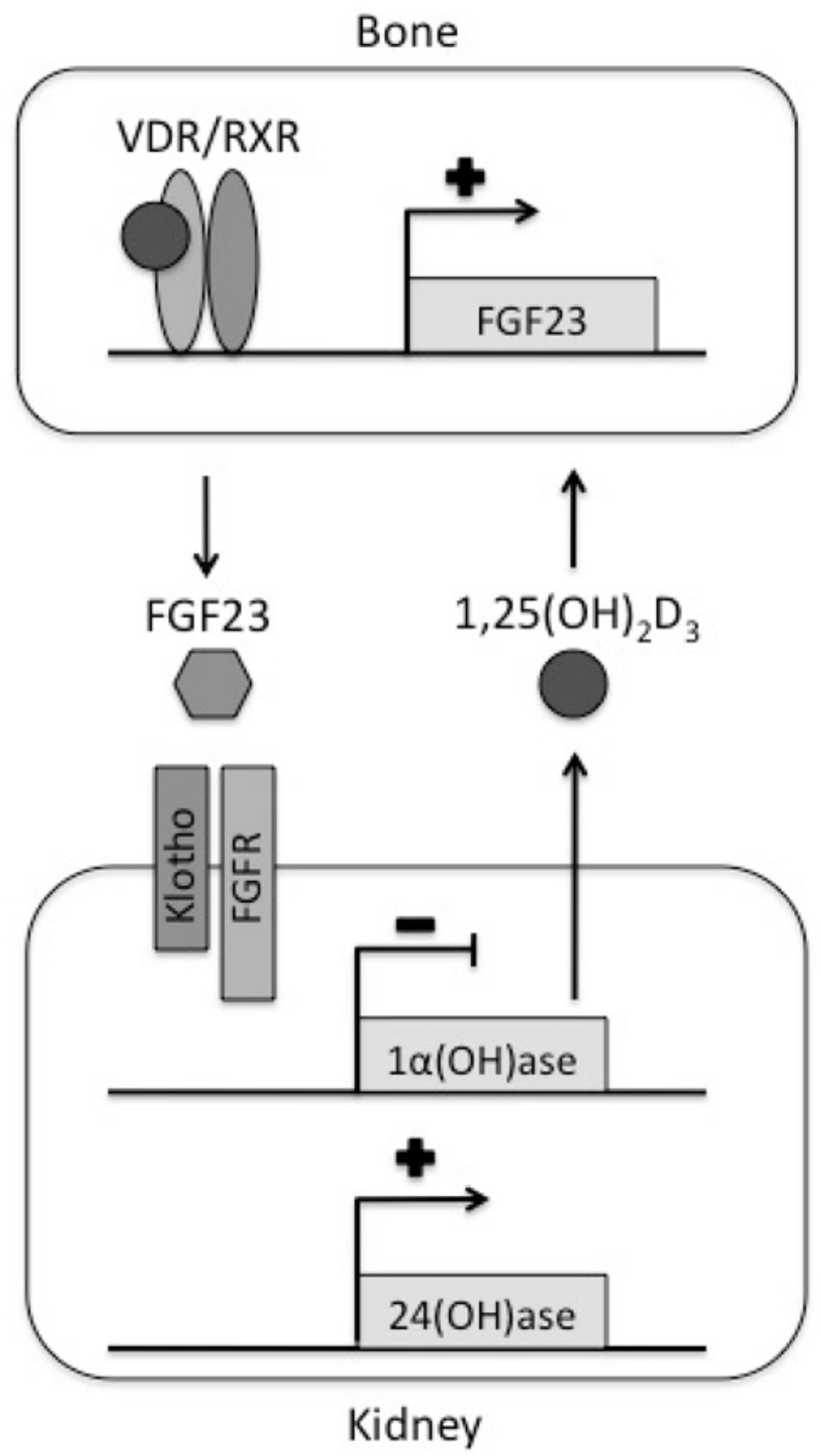

Fig. 2.

Regulation of vitamin D hydroxylases by FGF23-Klotho. $1,25(\mathrm{OH})_{2} \mathrm{D}_{3}$ binds to VDR. The ligand-bound VDR forms a heterodimer with nuclear retinoid $\mathrm{X}$ receptor (RXR) resulting in increased the expression of FGF23 in osteocytes. Secreted FGF23 activates FGFR bound by klotho in renal tubular cells. FGF signaling suppresses expression of $1 \alpha(\mathrm{OH})$ ase and induces $24(\mathrm{OH})$ ase thereby inhibiting synthesis and promoting catabolism of $1,25(\mathrm{OH})_{2} \mathrm{D}_{3}$. Thus, the FGF23-Klotho results in decreased levels of $1,25(\mathrm{OH})_{2} \mathrm{D}_{3}$.

Adapted from Kuro-o M (2008) Endocrine FGFs and Klothos: emerging concepts. Trends Endocrinol Metab 19:239-245 